\title{
Structural Development of the Oat Plant
}

\author{
PETER B. KAUFMAN AND THOMAS G. BROCK \\ University of Michigan \\ Ann Arbor, Michigan
}

The anatomical structure and morphology of the oat plant (Avena sativa $\mathrm{L}$.) have been reviewed previously by Hector (1936), Bonnett $(1961 \mathrm{a}, \mathrm{b})$ and Coffman (1977). In addition, Bonnett published detailed accounts of oat panicle development $(1937,1961 \mathrm{a}, \mathrm{b})$. This work has been summarized by Esau in her book, Anatomy of Seed Plants, in 1977. It is not the purpose of the present authors to simply go over all this same material again in a repetitive fashion, but rather, to emphasize some of the more recent and previously overlooked work on structural development of the oat plant, with emphasis on the major cultivated species, $A$. sativa (see Stanton, 1955; Coffman, 1977 for descriptions of this species). The material presented here should be of use to oat breeders, agronomists, and plant physiologists.

\section{3-1 STRUCTURE OF THE VEGETATIVE OAT PLANT}

\section{3-1.1 Seedling structure}

\section{3-1.1.1 Light-Grown Seedlings}

The light-grown oat seedling initially consists of a cylindrical coleoptile (a sheathing leaf that protects the shoot apex and undeveloped leaves), the coleoptilar node, where the coleoptile is attached, a mesocotyl or first internode, a scutellum (cotyledon), epiblast, coleorrhiza, and seminal (seedling) root system.

At germination, the shoot portion of the seedling emerges from the apical end of the grain (caryopsis). The structure that emerges first is the coleoptile. Anatomically, the coleoptile consists of inner and outer epidermises, ground parenchyma tissue between the two epidermises, and two vascular bundles. As the seedling develops in the light, the first true leaf emerges from the coleoptile through an apical pore. The first true leaf consists of a blade portion only, with no sheath present, in contrast to later-formed leaves. Exceptional detail of oat coleoptile structure is depicted in Avery (1930), Avery and Burkholder (1936), Bohmer (1958), Thimann and O'Brien (1965), and O'Brien and Thimann $(1965,1967)$.

Copyright (C) 1992 American Society of Agronomy and Crop Science Society of America, 677 S. Segoe Rd., Madison, WI 53711, USA. Oat Science and Technology-Agronomy Monograph no. 33 . 


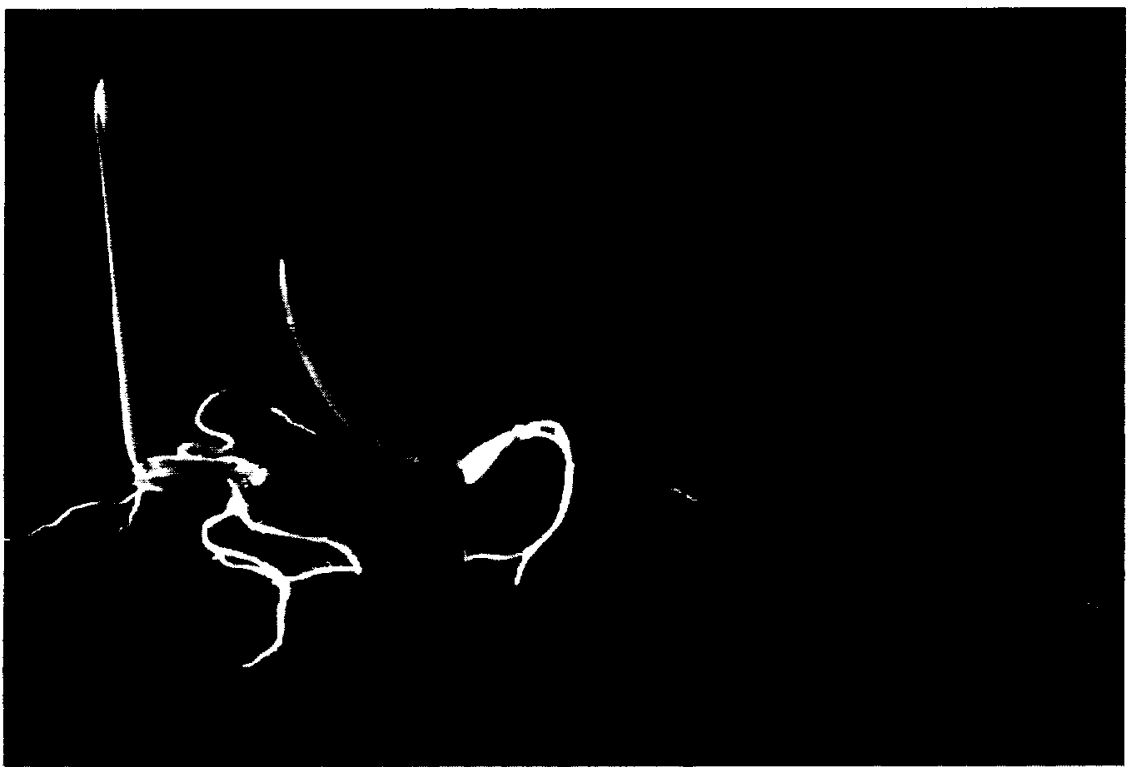

Fig. 3-1. Early development in light-grown oat seedlings. The first true leaf has emerged from the coleoptile of the seedling on the left. The coleoptile of the seedling on the right is displaying the bending characteristic of gravitropism.

From the initiation of emergence, the coleoptile manifests competency for negative gravitropism, or upward growth, regardless of initial orientation with respect to gravity (Fig. 3-1). Coleoptile elongation is largely regulated by the hormone, auxin (indole-3-acetic acid), which is produced by the coleoptile tip, moves basipetally via an active transport system, and promotes cell elongation in a growth zone located below the tip. Since gravitropism is, finally, asymmetric growth, oat coleoptile gravitropism is an auxinregulated process. The physiology of auxin action in oat growth and gravitropism is discussed further in Thimann (1977), Kaufman and Song (1987), and Kaufman et al. (1987).

In contrast to the coleoptile, the mesocotyl is very short in light-grown oat seedlings. It consists of an epidermis, cortical parenchyma, and several vascular bundles composed of primary xylem and phloem. Two of these vascular bundles are connected to the scutellum, or cotyledon, located at the base of the mesocotyl. The others connect with vascular bundles of the coleoptile above and the root vascular cylinder (stele) of the radicle, or seed root, below. Further anatomical detail of the oat mesocotyl is presented by Boyd and Avery (1936).

As noted above, the oat seedling has three specialized appendages other than the coleoptile: the scutellum, the epiblast, and the coleorrhiza. The scutellum and epiblast are inserted $180^{\circ}$ opposite each other at the base of the mesocotyl. The coleorrhiza surrounds the radicle or primary seminal root of the seedling. The scutellum is vascularized whereas the epiblast and the coleorrhiza are not (Boyd \& Avery, 1936). 
The root system of the seedling is composed of several seminal (seed) roots that arise from the scutellar node. Two or three adventitious roots may also emerge from the coleoptilar node. The anatomy of seminal roots consists of epidermis, cortex, endodermis, pericycle, and usually a hexarch (six primary xylem poles) vascular system. The vascular system of the primary seminal root is connected with vascular bundles that continue into the mesocotyl and scutellum above. The root-shoot transition region between the root stele and the individual vascular bundles of the mesocotyl occurs at the mesocotyl node (Boyd \& Avery, 1936).

\section{3-1.1.2 Dark-Grown Seedlings}

When oat seeds are drilled in the soil in field plantings or raised in the dark in the lab, plant morphology and pattern of development differ dramatically from that observed under light conditions. The coleoptile is more elongated than in a light-grown plant, but more obvious is the greatly elongated mesocotyl, or first internode. The adaptive significance of the latter is that extension of the oat mesocotyl in the soil, planting medium, or in the dark provides a mechanism for elevating the young leaves and shoot apex within the coleoptile to a light source for photosynthesis.

The internal anatomy of dark-grown seedlings is basically the same as described for light-grown seedlings except for the fact that all cells of the mesocotyl and coleoptile are much more elongated. The basic seedling structures, such as epiblast, scutellum, coleorrhiza, coleoptile, mesocotyl, young leaves, and adventitious and seminal roots are also present in the dark-grown oat seedling. It is the altered expression of mesocotyl and coleoptile development, in the form of enhanced cell elongation, that is so dramatically different in light-vs. dark-grown oat seedlings.

\section{3-1.2 Vegetative Shoot and Root Systems}

\section{3-1.2.1 External Structure}

The vegetative shoot system of the oat plant is composed of the culms (stems), each composed of a succession of alternating nodes and internodes (Fig. 3-2). The basal internodes are relatively short in length. The longest internodes occur towards the top of the culm, with the longest being the peduncular internode that supports the panicle inflorescence. At each node is a single leaf and in the axis of each leaf is an embryonic tiller shoot. The tip of the culm is referred to as the shoot apex.

Oat leaves are arranged distichously, or alternate in two ranks, with one leaf per node. Each leaf is composed of a sheath, which surrounds the culm, a ligule inserted at the apex of the sheath, and a leaf blade. New leaves emerge, blades first, in a sequential fashion from the sheaths of the next oldest leaf, as the shoot system develops. As the shoot matures, the oldest leaves lose their chlorophyll, cease to function photosynthetically, turn brown, and then gradually wither on the shoot. This process is termed leaf senescence. 


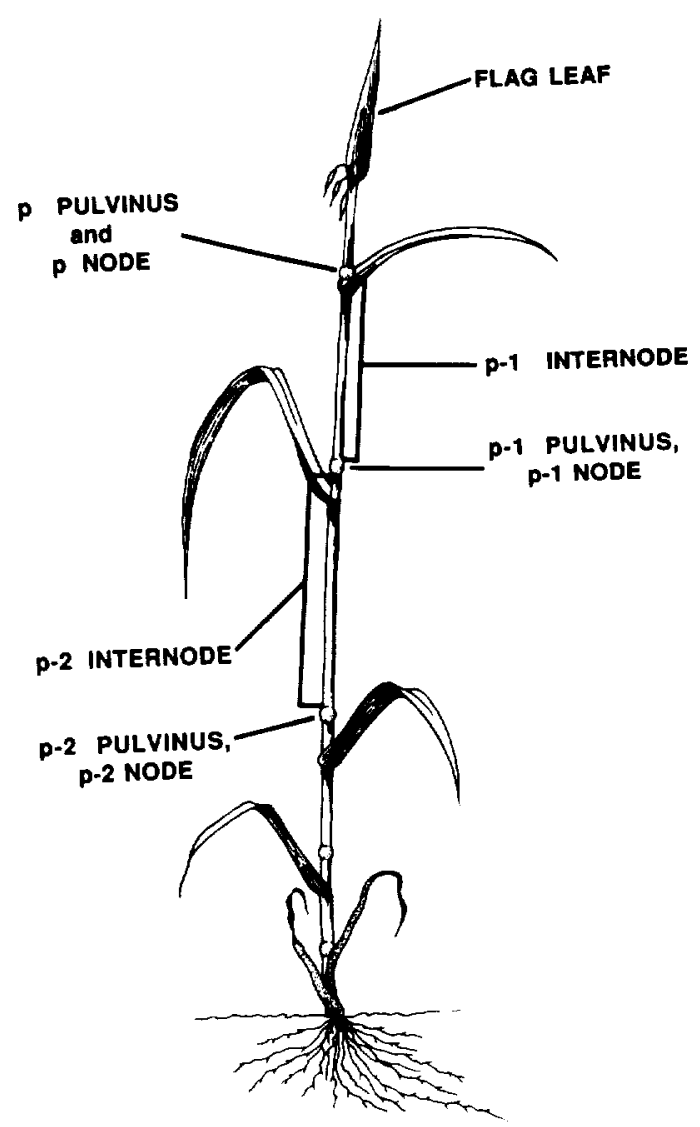

Fig. 3-2. Nomenclature of the node-internode system of the oat plant. The peduncular node, or "p node," is used as the point of reference. The associated pulvinus, on the leaf sheath of the flag leaf (which is located above the p node), is designated as the "p pulvinus." Nodes, pulvini, and internodes below the peducular node are designated sequentially, as $\mathrm{p}-1, \mathrm{p}-2$, etc.

As the plant grows, basally located secondary tiller shoots may begin to emerge from the lowest nodes (Fig. 3-3). The uppermost tiller buds, in contrast, remain quiescent. These upper tiller buds may be induced to form tiller shoots when the vegetative shoot becomes lodged (falls over due to action of wind or rain) (Fig. 3-4). The basal tiller buds are also accelerated in their development by lodging (Harrison \& Kaufman, 1980, 1982). Secondary tiller development is also promoted by the emergence of the panicle, or by the removal of the top of the main culm.

The root system of the vegetative plant is fibrous in nature throughout the life of the plant. The fibrous seminal roots of seedlings can be seen in Fig. 3-1. After the seedling stage, many of the seminal roots senesce. The root system then consists largely of branched adventitious roots that emerge from the basal-most nodes of the oat shoot (see, e.g., Fig. 3-3). These roots are also fibrous. The uppermost adventitious roots serve the additional func- 


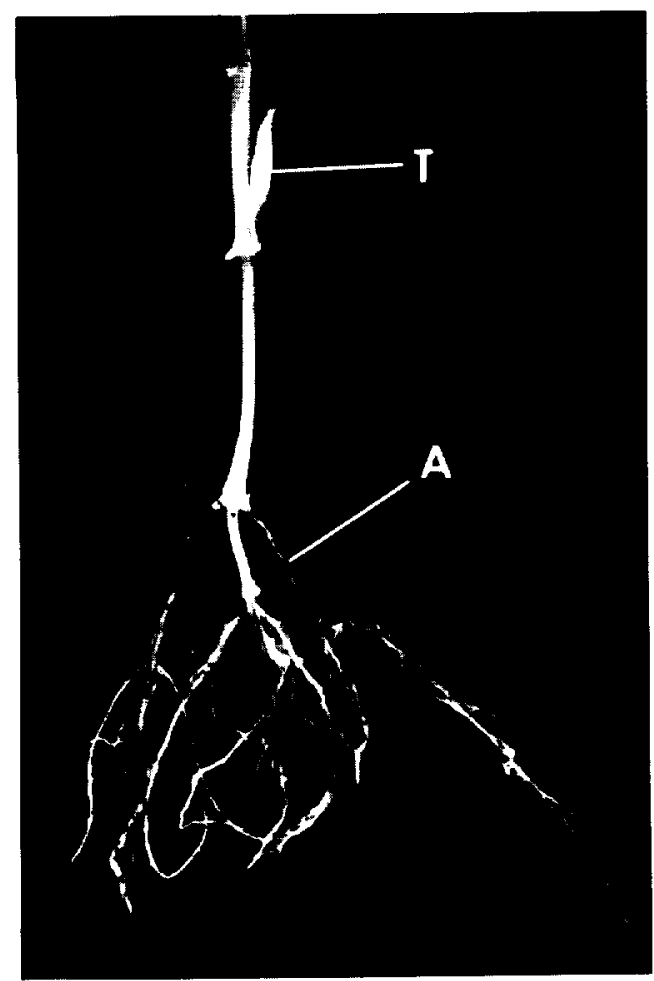

Fig. 3-3. A tiller shoot emerging from a leaf axil near the bottom of the oat culm. Note the adventitious roots emerging from the node below. $\mathrm{T}=$ tiller shoot; $\mathrm{A}=$ adventitious root.

tion of supporting the plant. These "prop" roots of oat are less prominant than those of larger plants, such as those of corn (Zea mays L.). Adventitious roots may also emerge from upper nodes in the stem of lodged main shoots, and from nodes near or in contact with the soil. Adventitious roots may also arise from the nodes of tiller culms that develop at the base (crown) of the shoot system.

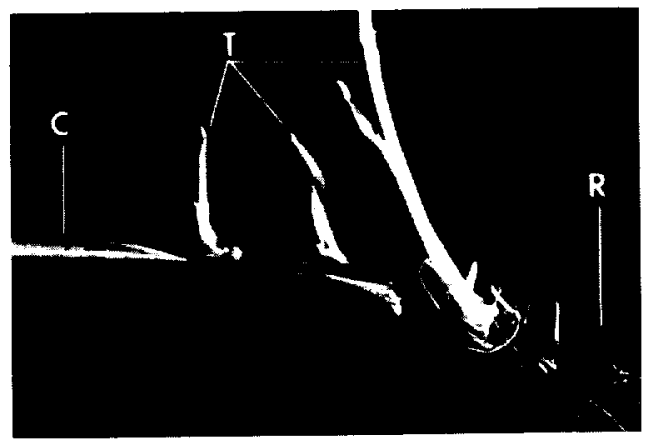

Fig. 3-4. Tiller shoots emerging from a prostrated (lodged) culm. $\mathrm{C}=$ main culm, $\mathrm{T}=$ tiller shoots, $R=$ root system. 


\section{3-1.2.2 Node and Internode System}

As mentioned previously, each culm of the vegetative oat shoot is made up of a series of alternating nodes and internodes. The nodes are sites of insertion of leaves and tiller (axillary) buds, one occurring at each node. The node is also a site where vascular bundles from the leaf and axillary bud (and adventitious roots when present) associated with this node and from the internode above and below all converge in an anastomizing vascular plexus (Chrysler, 1906).

Each node subtends a leaf-sheath pulvinus. The pulvinus is an enlarged region surrounding the stem at the base of each leaf sheath, distal to the node, and is the site of shoot gravitropism. The bending of the shoot, characteristic of gravitropism, is limited to this node-pulvinus region. This site of elbowlike bending is commonly referred to as a joint.

Each mature internode of the vegetative oat shoot is a hollow cylinder with a large, cylindrical lacuna (air space) in the center (Fig. 3-5A). Its anatomy consists of outer epidermis, ground or cortical parenchyma, two rings of vascular bundles, and an inner epidermis (Fig. 3-5B). This type of structure is also illustrated by Esau (1977).

Close to the periphery of the stem, just inside the epidermis, is a continuous cylinder of sclerenchyma in which the smaller vascular bundles of the outer ring are embedded. Strands of fibers also occur between these small vascular bundles. The internodes owe their structural support capability not only to the cellulosic cell walls of the internodal parenchyma cells, but also to lignin and amorphous silica gel $\left(\mathrm{SiO}_{2} \cdot \mathrm{nH}_{2} \mathrm{O}\right)$. Lignin occurs in the cell walls of subepidermal sclerenchyma, and silica gel is found in cell walls of the outermost internodal cells, which are primarily epidermal cells together with some sclerenchyma and cortical parenchyma cells (Kaufman et al., 1969a; 1970a; 1971; Simpson \& Volcani, 1981).

Finally, it is important to note that internodes of oat become green, hence photosynthetic, during their extension out of surrounding leaf sheaths. The photosynthetic tissue is called chlorenchyma. It corresponds to the cortical parenchyma that is, or has not yet become, sclerified (lignified). However, as the internode ages, it loses its chlorophyll, concomitantly with increasing silicification and lignification of the internode, and turns off-white to yellow. This corresponds to the stiff straw stage seen in mature oat culms.

\section{3-1.2.3 Internodal Elongation During Development}

Each internode and node of the vegetative oat plant arises just below the shoot apex, originating from cellular derivatives of the tunica and corpus of the apical meristem (Kleim, 1937). Nodes gradually become separated from internodes due to the cell division activity of a peripheral meristem and a central rib meristem in the developing internodes (Kaufman et al., 1965). For the first one-third of internodal elongation, growth by cell division predominates, initially throughout the internode, later at the periphery, and then at the base (Fig. 3-6). The localization of cell division activity to the 

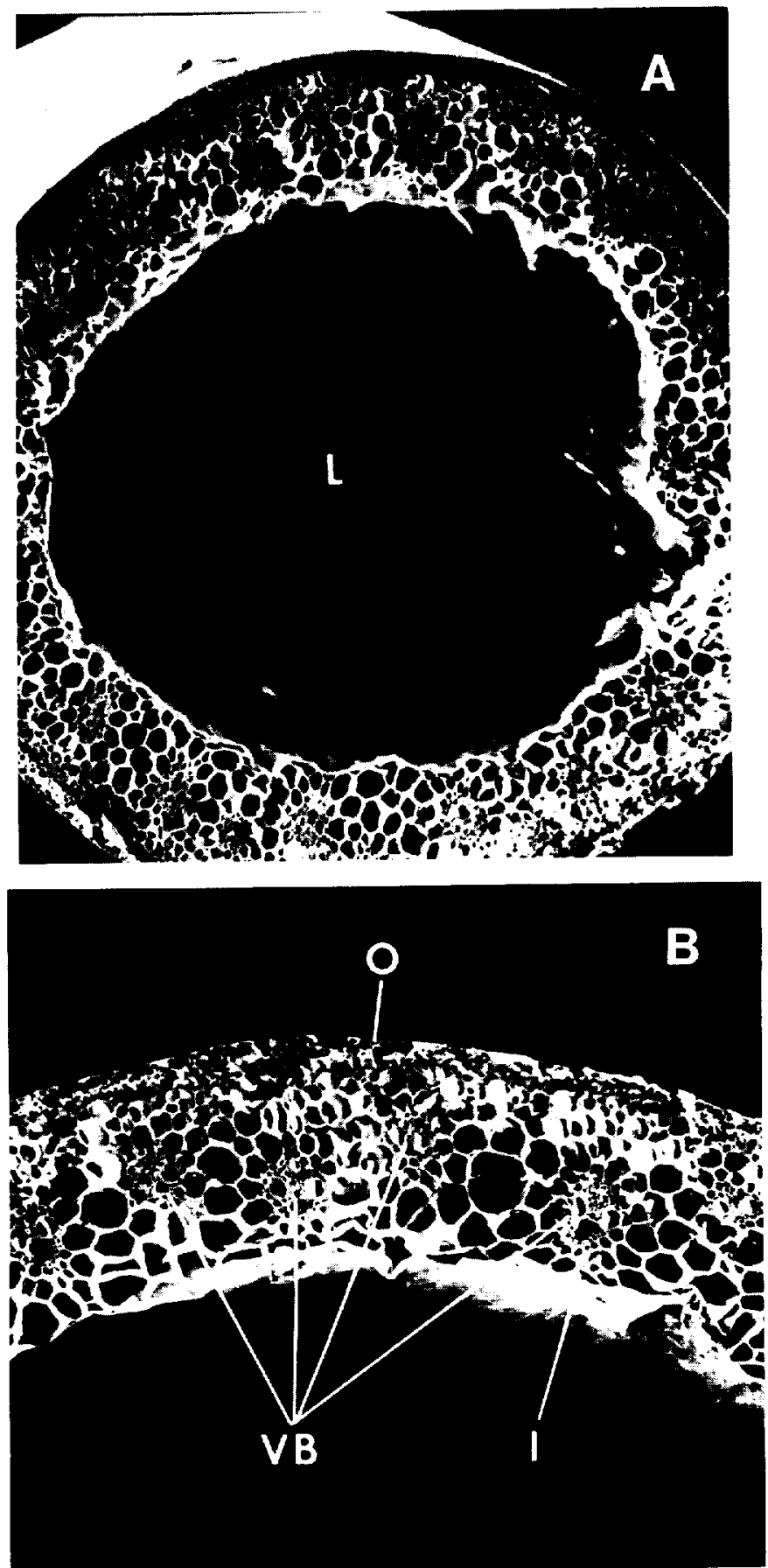

Fig. 3-5. Scanning electron micrographs of a cross section of the internode. $(A) \times 30$. (B) $\times$ 50. $\mathrm{L}=$ lacuna, $\mathrm{O}=$ outer epidermis, $\mathrm{VB}=$ vascular bundles, $\mathrm{I}=$ inner epidermis 


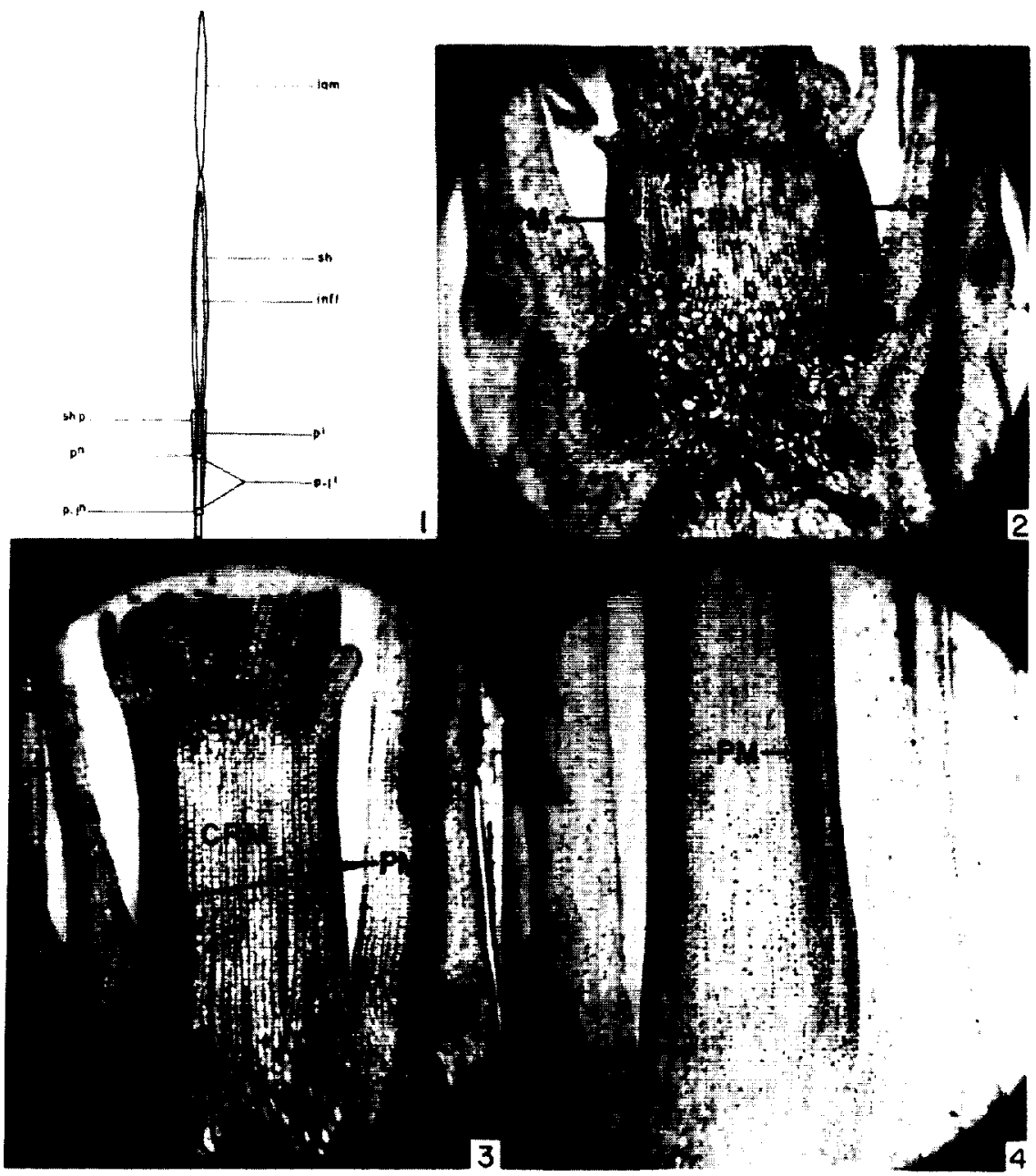

Fig. 3-6. Localization of meristematic activity during elongation of the p-1 internode. (1) Diagrammatic representation of the oat culm, identifying the site of the $\mathrm{p}-1$ internode. lam $=$ flag leaf lamina, $s h=$ flag leaf sheath, infl $=$ inflorescence, $s h^{p}=$ peduncular leaf sheath, $p^{i}=$ peduncular internode, $p^{n}=$ peduncular node, $p-1^{n}=$ subpeducular internode, $p-1^{n}$ = subpeduncular node. (2-4) Meristematic sites at Day 1 (2), Day 3 (3), and Day 8 (4) of p-1 internode elongation. $\mathrm{CRM}=$ central rib meristem, $\mathbf{P M}=$ peripheral meristem.

base of the developing internode as cells above elongate and differentiate is referred to as intercalcary growth. The basal region in the internode where mitotic activity persists is referred to as an intercalary meristem. The frequency of cell divisions in this meristem and the kinds of epidermal cells that differentiate from this meristem in internodes of Avena shoots are further described in Kaufman and Cassell (1963) and in Kaufman et al., (1965, 1970a,b, 1971).

For the last two-thirds of the period that oat internodes elongate, growth by cell elongation predominates, and this occurs in the basal part of the in- 

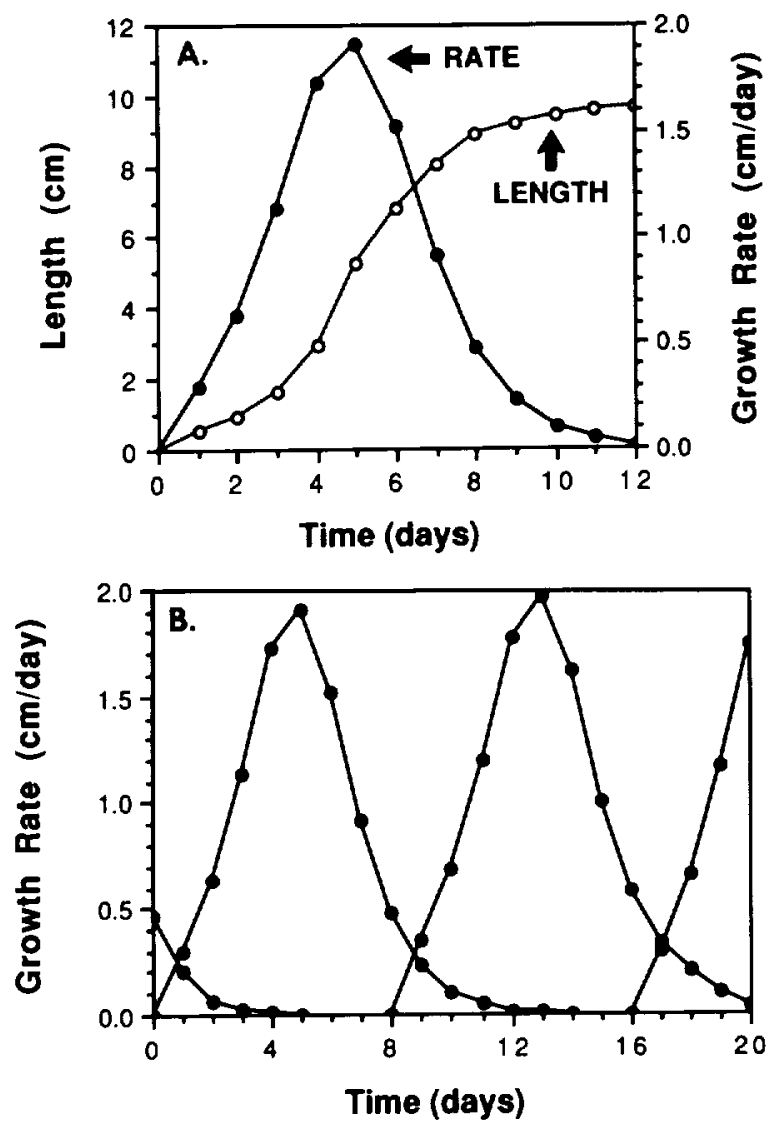

Fig. 3-7. The growth kinetics of oat internodes. (A) The growth and rate of growth of the p-2 internode during the entire period of internode elongation. (B) The growth rates of successive internodes ( $\mathrm{p}-3$ through $\mathrm{p}-1$ ) over a period of $20 \mathrm{~d}$, indicating the change in rate of one internode relative to that of the next internode.

ternode (Kaufman et al., 1965). This has been ascertained by analyzing the growth of individual epidermal cells along the internode. Growth in the internode is greatest towards the base of the internode, near the intercalary meristem. The elongation growth of the individual internode begins very slowly (Fig. 3-7A). The internode then releases with a burst of growth, with the majority of its elongation occurring over the next 4 to $5 \mathrm{~d}$. This burst of growth may be most easily seen as the change in the rate of growth, the change in length per day. The highest rates are limited to only a few days during the growth period of an internode.

As noted earlier, successive internodes elongate in a sequential fashion. One internode begins to elongate as the previous internode finishes its growth (Fig. 3-7B). As the previous internode ceases elongating, the next enters its burst of growth. This arrangement leaves the resources of the plant available to the individual internode during its period of greatest rate of growth. 
The process of internode elongation is regulated by several plant hormones. The gibberellins appears to play the major role, acting as promoters. Auxin (IAA), cytokinins, and abscisic acid differentially repress gibberellinpromoted intercalary growth (Kaufman, 1965a,b, 1967; Kaufman et al., 1969b; Jones \& Kaufman, 1971; Kaufman \& Jones, 1974; Koning et al., 1977; Kaufman \& Dynanandan, 1983). Very short cultivars, or dwarfs, are typically characterized by a deficiency in or insensitivity to gibberellin.

As internodes cease elongating, they stiffen due to lignification and silicification, especially in outer regions of the internode. The silicification process involves the polymerization of monosilicic acid, $\mathrm{Si}(\mathrm{OH})_{4}$, derived from the xylem, to amorphous silica gel, $\mathrm{SiO}_{2} \cdot \mathrm{nH}_{2} \mathrm{O}$ in cell walls of epidermal and cortical parenchyma of the internode (Kaufman et al., 1981). Both lignification and silicification of internodal cell walls start first at the top of the developing internode, near the node, and progress towards the base during internodal elongation, until the entire outer portion of the internode from top to bottom is silicified and lignified. This last stage occurs when the internode has begun to emerge from the leaf sheath. In short-statured, semi-dwarf cultivars of oat, rice, and wheat, the culm internodes are stiffer due to enhanced silicification. This, combined with the fact that the internodes of the semi-dwarfs remain wrapped by the leaf sheaths, makes these plants more resistant to lodging (Kaufman et al., 1981).

\section{3-1.2.4 Origin, Development, and Structure of Tiller Shoots}

As noted earlier, axillary buds develop into lateral shoots termed tillers in cereal grasses (Fig. 3-8; see also Fig. 3-3 and 3-4). In vegetative shoots,

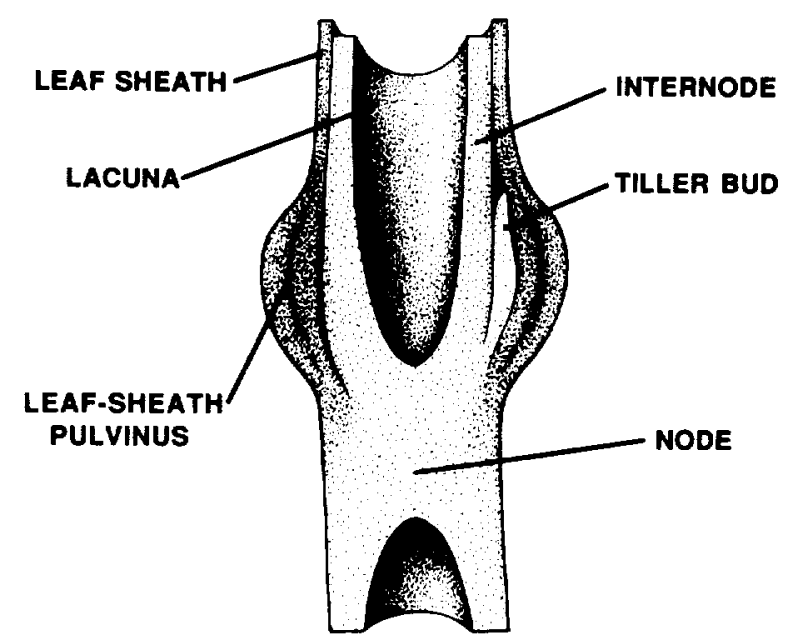

Fig. 3-8. Detail of the morphology of the pulvinus-node region of an oat shoot, as would be seen in median longitudinal section. Note that the leaf-sheath pulvinus is at the base of the leaf-sheath, encircling the base of the internode and distal to the node. The tiller bud is inserted into the axil of the sheathing leaf base. 
a single axillary bud is inserted in the axil of each leaf. Axillary buds are initially formed in young leaf axils relatively close to the shoot apical meristem and are usually first evident three nodes below the shoot apex. They arise as meristematic protuberances from the basal peripheral region of the partially elongated internode. Each protuberance forms the lateral apical meristem of the axillary bud. The first axillary bud appendage to appear is a prophyll, a two-keeled structure that surrounds the axillary bud shoot apex. It functions to protect the bud much as a coleoptile does in the seedling. The first-formed axillary buds located near the base of the main culm remain quiescent for a time (several weeks), then break through the leaf sheaths that surround them to emerge as tiller shoots. A succession of tiller shoots (three to four) may emerge from basal nodes to form lateral culms, and these may ultimately form panicles. The axillary buds above the base of the plant remain quiescent and usually only develop if the main culm becomes lodged.

The process of tiller shoot emergence in oat is under auxin/cytokinin control. Cytokinin promotes tiller shoot emergence whereas auxin suppresses it. It is the ratio of auxin to cytokinin that is of primary importance in this regulatory mechanism (Harrison \& Kaufman, 1980, 1982). Several factors may change this ratio in favor of elevated cytokinin levels that result in the release of axillary buds from quiescence. These include: (i) lodging, (ii) herbivory or mechanical decapitation of the main culm, and (iii) emergence of the inflorescence from the flag leaf.

\section{3-1.2.4 Origin and Development of Leaves}

Each leaf of the oat shoot originates as a lateral protuberance, termed a leaf primordium, along the flank of the apical meristem. Both tunica (outer layers) and corpus (central portion) of the shoot apex contribute to its development. Each successive leaf primordium arises from the shoot apex $180^{\circ}$ opposite the previously formed one. This results in the leaves developing alternately in two ranks along the shoot in what is termed a distichous phyllotaxis, or two-ranked leaf arrangement (refer to Fig. 3-2).

As the leaf primordium develops, it forms a hood-shaped structure over the shoot apex. Its basal region is attached to the lower flank of the apex over one-half of its circumference. This hood-shaped structure is the future leaf blade or lamina. Following this hood stage, the young leaf elongates rapidly upward through the sheath of the next oldest leaf by basal intercalary growth. By the time two more leaves have been initiated, the base of the leaf develops a sheath. At the juncture between this young sheath and the base of the blade, a ligule is initiated from the young inner (adaxial) epidermal layer. Following ligule initiation, the blade begins to emerge from the sheath of the leaf that surrounds it. The appearance of the blade coincides with the time for rapid intercalary growth that occurs in the basal portion of the leaf sheath below. The last phase of leaf development is marked by completion of sheath intercalary growth; this occurs when the top of the 
sheath, just below the ligule region, emerges from the sheath of the next oldest leaf (same leaf from which the blade had emerged earlier). The total time of leaf development may be as many as five to seven plastochrons (a plastochron is a developmental time index, one plastochron being the time that elapses between the initiation of two successive leaf primordia from the shoot apex).

\section{3-1.2.6 Structure of Mature Leaves}

The mature leaf of oat consists of a leaf blade, the ligule and collar, a leaf sheath and the leaf-sheath pulvinus. The leaf blade is composed of an upper (adaxial) and a lower (abaxial) epidermis, photosynthetic mesophyll parenchyma, and both longitudinal and cross-connecting (commissural) vascular bundles (Bonnett, 1961b; Kaufman et al., 1985). Figure 3-9 illustrates the anatomical structure of the oat leaf blade as seen in cross section.

The adaxial (upper) epidermis of the leaf blade consists of long epidermal cells that have undulating cell walls and may be lignified over sites of vascular bundles, clusters of bulliform cells between vascular bundles and rows of stomatal complexes and trichomes (hairs) (Fig. 3-10). Rows of corksilica pairs also occur on the upper epidermis, running parallel to the vascular bundles. The bulliform cells of the upper epidermis collapse as the leaf encounters severe drought or steep drops in water potential, resulting in a

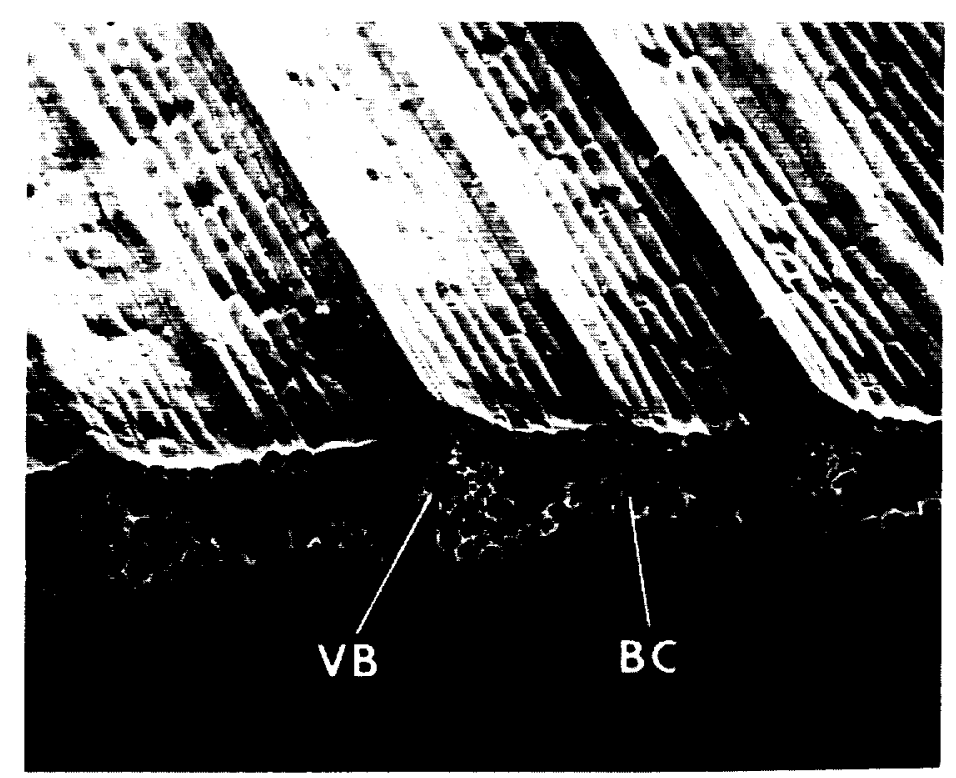

Fig. 3-9. Scanning electron micrograph of cross section of leaf blade. This view is of the lower (abaxial) surface, $\mathrm{BC}=$ bulliform cell cluster, $\mathrm{VB}=$ vascular bundle $\times 100$. 

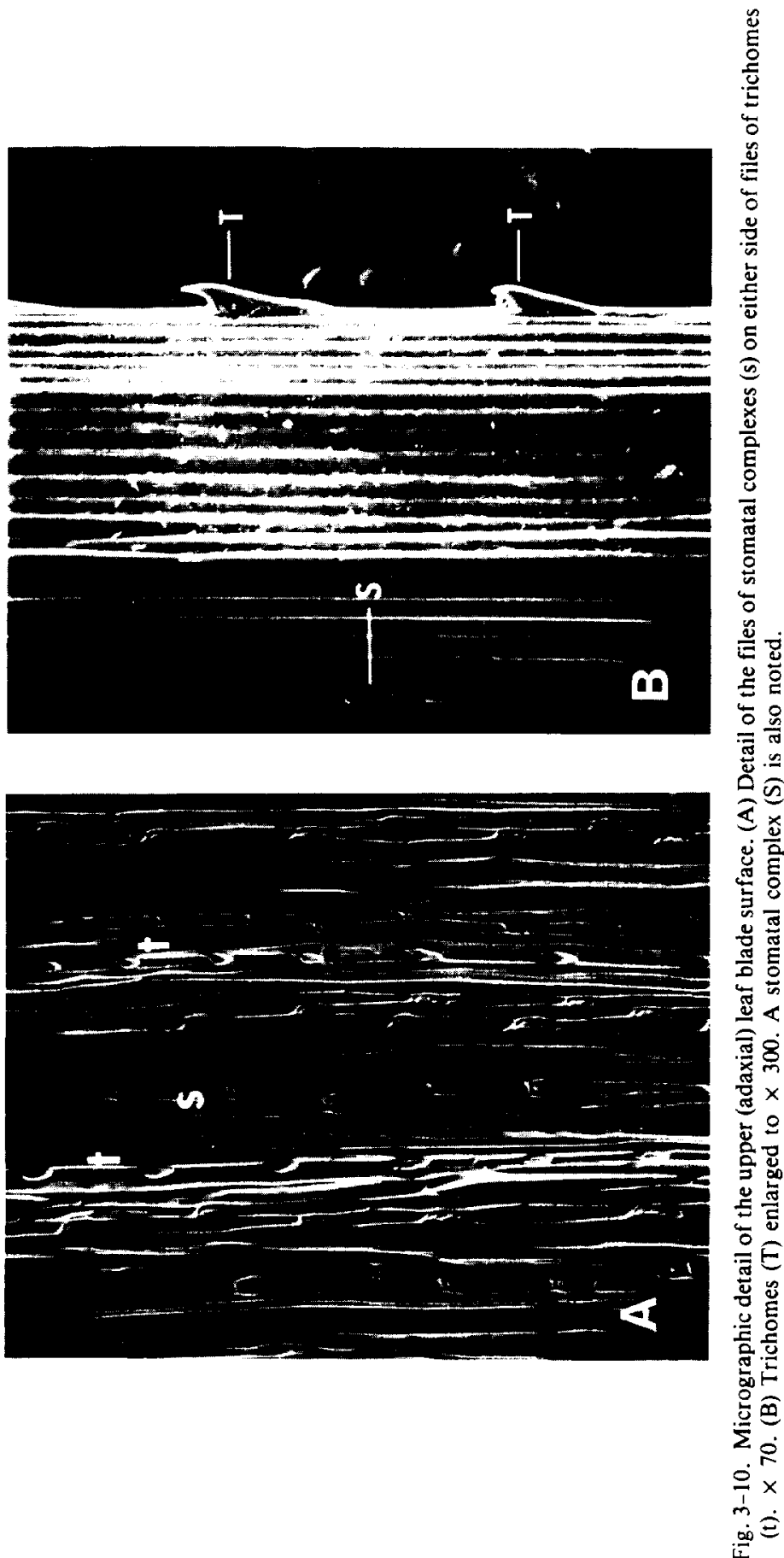
rolling up of the leaf blade. These cells regain turgor when moisture again becomes available and the water potential becomes less negative, resulting in an unrolling of the leaf blade.

The abaxial (lower) epidermis of the blade is made up primarily of long epidermal cells with rows of stomata paralleling and lying on each side of the vascular bundles (Fig. 3-11). Trichomes and bulliform cells are lacking. Each stomatal complex has a pair of guard cells and two subsidiary cells. Rows of stomatal complexes are found adjacent to ridges overlying vascular bundles. No bulliform cells are associated with the lower epidermis.

The mesophyll of the leaf blade forms the matrix of photosynthetic tissue, interspersed among large intercellular spaces between the upper and lower epidermises (Bonnett, 1961a). It is located between and around the longitudinally oriented vascular bundles. Along the leaf margin, and above and below the largest longitudinal vascular bundles, highly lignified sclerenchyma may also be found (Esau, 1977; Bonnett, 1961a). The vascular bundles are composed of primary xylem and primary phloem surrounded by a bundle sheath. The bundle sheath in turn is made up of an outer ring of thin-walled, chloroplast-containing cells and an inner ring of thick-walled, chloroplastless mestome sheath cells.

Below the leaf blade and atop the leaf sheath is the collar and ligule. The collar region is the joint region within the leaf where the ligule is attached and is whitish-colored due to reduced chlorophyll content and chloroplast number. The ligule is a paper-like vertical appendage (Fig. 3-12). Its anatomical structure and function are also described in Bonnett (1961a). A few oat subspecies are devoid of ligules, as for example, in A. sativa ssp. orientalis Schreb. (Stanton, 1955).

The leaf sheath is highly lignified and silicified at maturity. Lignification in the sheath is attributed to the presence of strands of lignified fibers, vessel elements, and tracheids associated with the vascular bundles as well as lignified, thick-walled epidermal cells. As a result, the sheath provides substantial support, especially for developing internodes and leaves enclosed within. The sheath is also a site of photosynthesis. A region of chlorenchyma lies near the outer (abaxial) side of the sheath in layers of three or more cells between the vascular bundles; inner (adaxial) parenchyma in the sheath lacks chloroplasts. As the sheath matures, numerous air spaces develop in the parenchyma, resulting in a loss in the ability of the sheath at this stage of development to support the inner portions of the shoot. At maturity, the sheath turns brown, and it is gradually sloughed away from the shoot.

Vascular bundles within the sheath are similar to those described for the blade. The outer epidermis is made up of long epidermal cells interspersed with rows of stomatal complexes and cork-silica cell pairs. The inner epidermis is composed of long epidermal cells interspersed with a few stomata. The surface of the leaf sheath is highly cutinized, making it an effective barrier to water loss, particularly for young tissues retained within it. Further details on the anatomical structure of the sheath are discussed in Bonnett (1961a). 


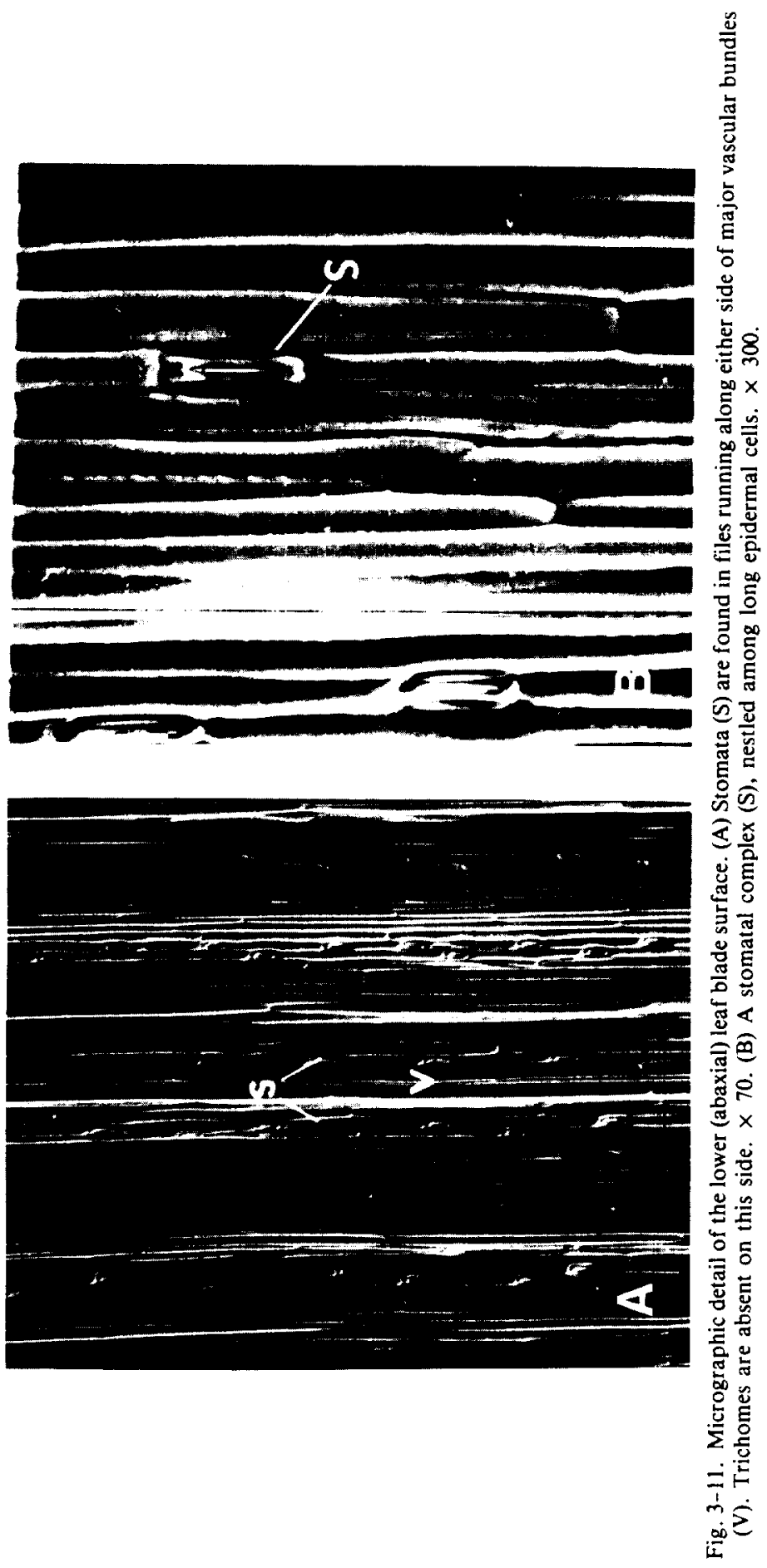




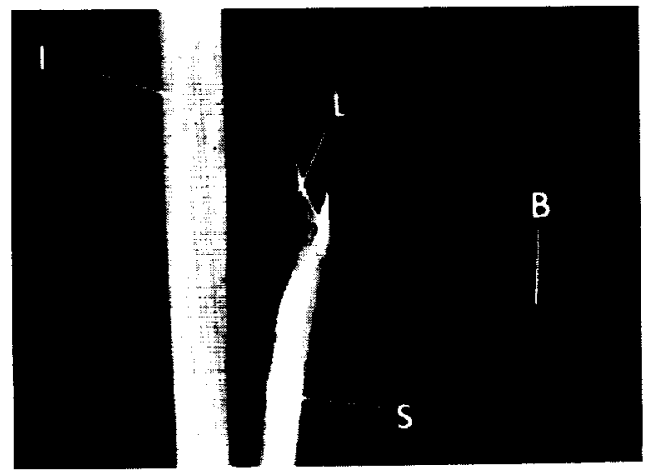

Fig. 3-12. The ligule-collar region of the oat leaf. $\mathrm{I}=$ internode, $\mathrm{B}=$ leaf blade, $\mathrm{L}=$ ligule, $\mathrm{S}=$ leaf sheath. $\times 2.5$.

At the base of the leaf sheath, distal to the node, is a swollen region referred to as the leaf-sheath pulvinus. Upward bending in this region results in the shoots returning to the vertical position when they have become prostrated (lodged) by wind or rain. The structure of the leaf-sheath pulvinus is unique (Bonnett, 1961a; Brown et al., 1959; Dayanandan et al., 1977; Dayanandan \& Kaufman, 1984). It is composed of nonlignified and nonsilicified cells in the epidermal layer in contrast to the reverse situation in the sheath above and in the internode below (Arslan \& Bennet-Clark, 1960; Dayanandan et al., 1977). Within the pulvinus is a matrix of parenchyma cells and a ring of vascular bundles. Each bundle has a conspicuous cap of nonlignified collenchyma tissue lying toward the outer side of the sheath.

The cells of the leaf-sheath pulvinus are capable of responding to gravistimulation or lodging by elongating preferentially on the lower side of the plant. The site of graviperception resides in cells (statocytes) central to the vascular bundles (Song et al., 1988). The statocytes are easily visualized by staining with iodine, as they contain starch-filled chloroplasts, or statoliths, and the starch grains become dark blue upon staining. The upward bending response in the leaf-sheath pulvinus is regulated by the phytohormones gibberellin and auxin (Kaufman et al., 1987; Brock \& Kaufman, 1988a). These hormones stimulate differential growth across the pulvinus (Dayanandan \& Kaufman, 1984), producing the distinctive bending that is commonly observed at this joint. Like the internodes, the pulvini develop in succession, each gaining responsiveness as the one below matures (Brock \& Kaufman, 1988b).

\section{3-1.2.7 Origin, Development, and Structure of the Roots}

As mentioned earlier, the roots of oat plants are of two types: seminal (seed) and adventitious roots. The former originate from the embryo and function primarily during the seedling stage of development. Adventitious roots gradually replace the seminal root system after the seedling stage. They are formed from cells near the outer ring of vascular bundles of crown inter- 
nodes just above the subcrown internode. They emerge from main and tiller culms near their bases throughout the course of vegetative and early reproductive stages of shoot development. Each adventitious root possesses a root apex and a root cap that covers the apex. These roots may be branched, with the lateral roots originating well back of the root hair zone, usually from the pericycle.

Adventitious roots, as viewed in cross section, are made up of an epidermis, a cortical parenchyma, a ring of cortical sclerenchyma (two cell layers inside the epidermis), the endodermis (innermost layer of the cortex), a pericycle, and a polyarch vascular cylinder (stele). Sclerenchyma may also be present in the vascular cylinder. The anatomical structure of the adventitious and seminal roots of oat is illustrated in Bonnett (1961a) and in Harkes (1973).

\section{3-2 REPRODUCTIVE STRUCTURES AND THEIR DEVELOPMENT}

\section{3-2.1 Origin, Development, and Structure of the Panicle}

In oat, the inflorescence is a panicle. Panicle initiation is denoted by the appearance of first order branch primordia protuberances along the flanks of the shoot apex. Further development is marked by the appearance of primordia for second order branches of the panicle. Later stages of panicle primordia formation occur as spikelets are initiated (Bonnett, 1937, 1961a,b; Esau, 1977).

Branches within the panicle originate as whorls along the rachis, or main axis. As a result, panicles may be either equilateral, with branches arising from all sides of the rachis, or unilateral, with branches arising from one side (Stanton, 1955). The panicle of $A$. sativa is equilateral. Four to seven such whorls of branches occur along a rachis, with the lowermost whorl being longest and the uppermost shortest. Each branch of a panicle has one to several spikelets. The spikelets are composed of several florets, or individual flowers. Later stages in panicle development are denoted by elongation of branches from the rachis of the panicle and differentiation of glumes (bracts), florets and their constituent organs within the spikelets (Fig. 3-13).

As the rachis elongates, the panicle emerges from the collar of the flag leaf. Further elongation of the rachis and the branches holding the florets results in full presentation of the inflorescence (Fig. 3-14). By this point, the florets have developed sufficiently to begin pollination.

\section{3-2.2 Origin, Development, and Structure of the Floret}

The floret, as a technical term, refers to the individual flower of a multiflowered inflorescence (the complete cluster of flowers), and one or more florets occur in a spikelet. In cultivated oat, each spikelet usually has two to three florets. The floret is supported on a stalk called a rachilla. The apex of the rachilla bears two empty glumes, or bracts, and the florets. Each floret consists of a lemma and a palea (both are bracts), two lodicules, three sta- 


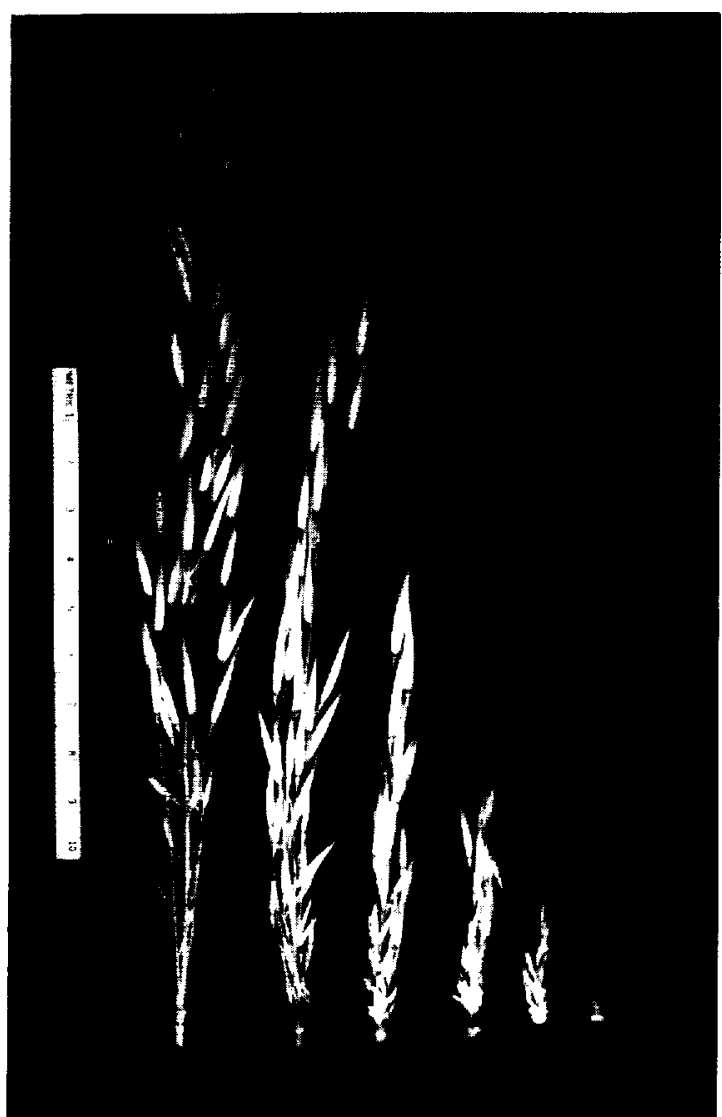

Fig. 3-13. Successive stages, from right to left, of panicle development.

mens and a pistil (composed of an ovary, a bifid or two-parted style, and plumose or feathery stigmas) (Fig. 3-15). The florets originate in developing spikelets of the panicle. The development of the various organs of the floret is beautifully illustrated by Bonnett (1961a) from the stage of early stamen and pistil differentiation all the way to protrusion of stigmas and styles and exsertion by anthers (just prior to anthesis). The lodicules are located at the base of the ovary and function to open the floret at anthesis because of their turgidity. They probably represent much reduced divisions of a perianth (Chase, 1950). Regarding the pistil, the reason there are usually two stigmas and styles, and not three as one would expect for monocots, is that early in the development of the pistil, one style and stigma abort. This is true for most grasses. Occasionally, two or none may abort, making it possible to find one or three styles or stigmas. In connection with the stigma itself, its plumose or feathery character aids in the trapping of pollen grains that are wind dispersed. 


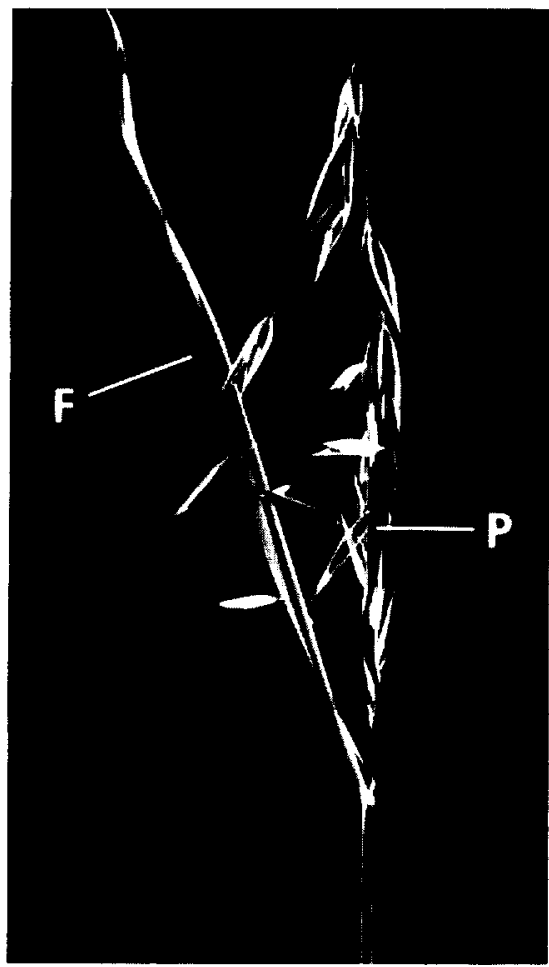

Fig. 3-14. An expanded inflorescence of the oat cultivar 'Victory'. This particular plant was raised under greenhouse conditions, and as a result the inflorescence is less robust than would be observed in a plant grown in the field.

\section{3-2.3 Pollination and Fertilization}

Oat flowers are self-pollinated, with flowers only rarely cross-pollinated. Anthers normally dehisce their pollen prior to and during opening of the floret, so that self-pollination occurs prior to any opportunity for wind pollination.

The pollen grains that are released by the anthers become trapped in the plumose branches of the stigmas of other florets. The pollen grains themselves look like minute oranges; they have a corrugated surface and a single pore. These features are typical of all grasses. The single-pored condition of the pollen is referred to as monocolpate pollen.

Events following anthesis and pollination, namely fertilization and development of the embryo and endosperm within the embryo sac, have been well documented and illustrated by Bonnett $(1961 \mathrm{a}, \mathrm{b})$. Bonnett has presented excellent photomicrographs illustrating egg, synergid, and antipodal cells of the embryo sac and early stages in development of the embryo and endosperm in the embryo sac following fertilization. A globular proembryo and free nuclei of the endosperm are evident $48 \mathrm{~h}$ after fertilization. As the embryo develops, it becomes torpedo-shaped. Just after this stage, the shoot and root apices become organized and a coleoptile primordium appears. As the embryo matures, it forms a lateral scutellum (cotyledon)next to the en- 


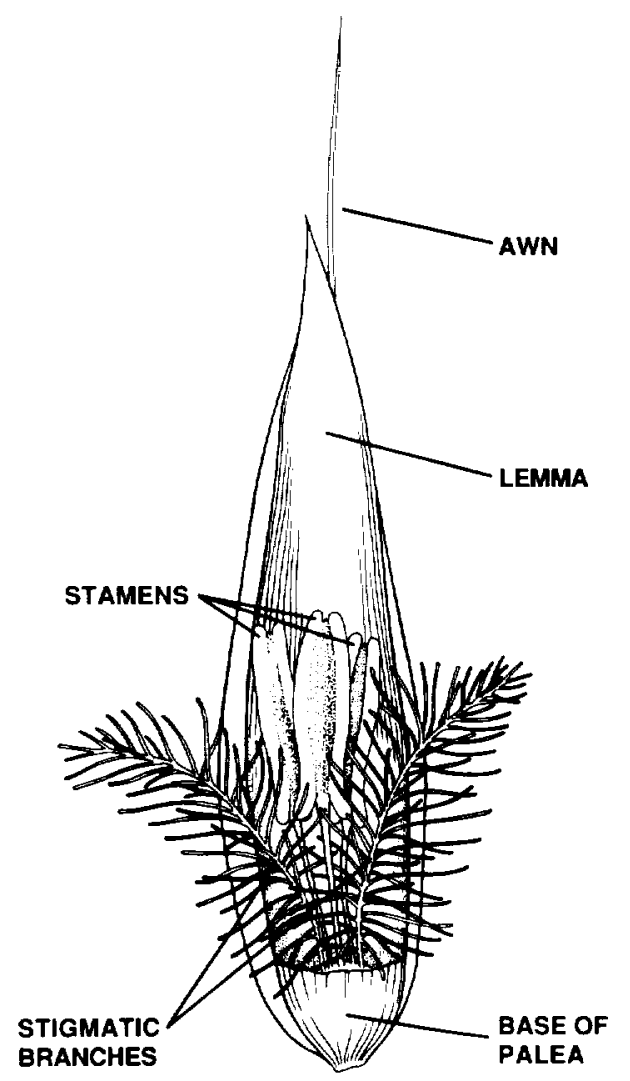

Fig. 3-15. Detail of a single floret, with most of the palea removed. At this point in floret development, the two plumose branches of the stigma are exserted and receptive, while the three stamens are still retained within the floret.

dosperm, a coleorrhiza over the root apex, and several leaf primordia within the coleoptile. Concomitant with these events, the endosperm becomes cellular (forms cell walls around the free nuclei) and its cells start to store starch as well as protein (in the peripheral aleurone layers).

\section{3-2.4 Structure of the Mature Oat Grain (Caryopsis)}

The mature grain of oat is surrounded by two protective, highly silicified husks, called the lemma and the palea. When both the lemma and the palea are removed, the naked grain, or caryopsis, is revealed. The caryopsis of 'Victory' is covered with conspicuous trichomes. This is typical of most cultivars. In transverse section, one observes a distinct crease in the grain. The grain, seen in this plane, is composed of the pericarp, the aleurone and subaleurone layers of the endosperm (filled with storage protein bodies) (Fig. 3-16), as well as phytin crystals (within the aleurone), the starchy endosperm and the embryo (germ). The pericarp is made up of what was formerly the 


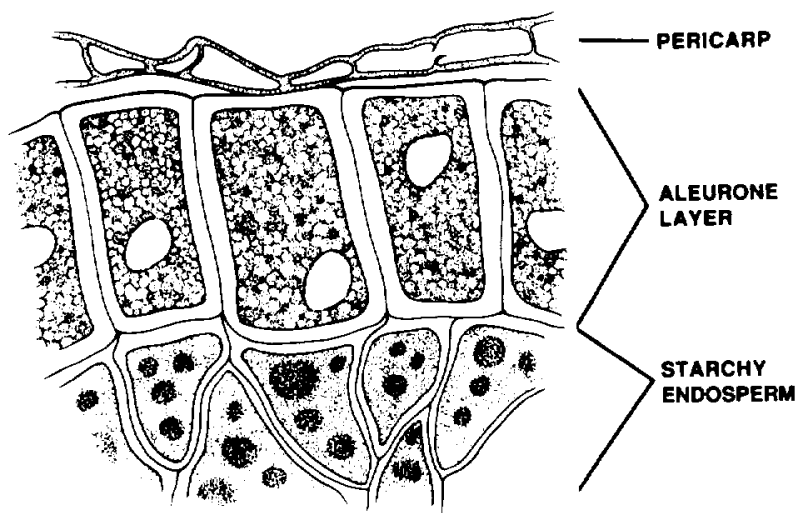

Fig. 3-16. Detail of the surface of the caropysis, as would be seen by microscopic inspection of a median longitudinal section. The cells of the outer epidermal layer, the pericarp, have dried out but are retained during grain maturation. A single layer of cells, the aleurone, lies interior to the pericarp and surrounds the starchy endosperm.

integuments and nucellus surrounding the embryo sac (see also Fulcher, 1986). The anatomical structure of the oat embryo is illustrated by Fisk and Millington (1962) and by Hector (1936). The structure of the aleurone layer and starchy endosperm is further described by Bechtel and Pomeranz (1981).

\section{ACKNOWLEDGMENT}

The authors are deeply indebted to Mr. David Bay for excellent photographic work and to Mr. David Rini for preparing the free-hand illustrations. Thanks are also due to Drs. David Peterson and Harold G. Marshall for helpful and constructive suggestions during the preparation of the manuscript. Support for preparation of this manuscript was kindly provided by grant NAG 10-0069 from the National Aeronautics and Space Administration.

\section{REFERENCES}

Arslan, N., and T.A. Bennet-Clark. 1960. Geotropic behaviour of grass nodes. J. Exp. Bot. 11:1-12.

Avery, G.S. 1930. Comparative anatomy and morphology of embryos and seedlings of maize, oats, and wheat. Bot. Gaz. 89:1-39.

Avery, G.S., and P.R. Burkholder. 1936. Polarized growth and cell studies on the Avena coleoptile, phytohormone test object. Bull. Torr. Bot. Club 63:1-15.

Bechtel, D.B., and Y. Pomeranz. 1981. Ultrastructure and cytochemistry of mature oat ( $A$ vena sativa $\mathrm{L}$.) endosperm. The aleurone layer and starchy endosperm. Cereal Chem. 58:61-69.

Bohmer, H. 1958. Untersuchungen uber das Wachstum und den Feinbau der Zechwande in der Avena-Koleoptile. Planta 50:461-497.

Bonnett, O.T. 1937. The development of the oat panicle. J. Agric. Res. 54:927-931.

Bonnett, O.T. 1961a. Morphology and development. p. 41-74. In F.A. Coffman (ed.) Oats and oat improvement. Agron. Monogr. 8. ASA, Madison, WI.

Bonnett, O.T. 1961b. The oat plant: Its histology and development. Illinois Agric. Exp. Stn. Bull. 672 . 
Boyd, L., and G.S. Avery, Jr. 1936. Grass seedling anatomy: The first internode of Avena and Triticum. Bot. Gaz. 97:765-779.

Brock, T.G., and P.B. Kaufman. 1988a. Altered growth response to exogenous auxin and gibberellic acid by gravistimulation in pulvini of Avena sativa. Plant Physiol. 87:130-133.

Brock, T.G., and P.B. Kaufman. 1988b. Competency for graviresponse in the leaf-sheath pulvinus of Avena sativa: Onset to loss. Am. J. Bot. 75:1672-1677.

Brown, W.V., G.A. Pratt, and H.M. Mobley. 1959. Grass morphology and systematics. II. The nodal pulvinus. Southwest. Nat. 4:126-130.

Chase, A. 1950. Manual of grasses of the United States. USDA Misc. Publ. 200. U.S. Gov. Print. Office, Washington, DC.

Chrysler, M.A. 1906. The nodes of grasses. Bot. Gaz. 41:1-16.

Coffman, F.A. 1977. Oat history, identification and classification. USDA Tech. Bull. 1516. U.S. Gov. Print. Office, Washington, DC.

Dayanandan, P., F.V. Hebard, V.D. Baldwin, and P.B. Kaufman. 1977. Structure of gravitysensitive sheath and internodal pulvini in grass shoots. Am. J. Bot. 64:1189-1199.

Dayanandan, P., and P.B. Kaufman. 1984. Analysis and significance of gravity-induced asymmetric growth in the grass leaf-sheath pulvinus. Ann. Bot. 53:29-44.

Esau, K. 1977. Anatomy of seed plants. 2nd ed. John Wiley and Sons, New York.

Fisk, E.L., and W.F. Millington. 1962. Atlas of plant morphology. Portfolio II. Photomicrographs of flower, fruit and seed. Burgess Publ. Co., Minneapolis.

Fulcher, R.G. 1986. Morphological and chemical organization of the oat kernel. p. 47-74. In F.H. Webster (ed.) Oats: Chemistry and technology. Am. Assoc. Cereal Chem. Inc., St. Paul, MN.

Harkes, P.A. 1973. Structure and dynamics of the root cap of Avena sativa L. Acta Bot. Neerl. 22:321-328.

Harrison, M.A., and P.B. Kaufman. 1980. Hormonal regulation of lateral bud (tiller) release in oats (Avena sativa L.). Plant Physiol. 66:1123-1127.

Harrison, M.A., and P.B. Kaufman. 1982. Does ethylene play a role in the release of lateral buds (tillers) from apical dominance in oats? Plant Physiol. 70:811-814.

Hector, J.M. 1936. Oat species (Avena) . p. 21-91. In Introduction to the botany of field crops. Central News Agency, Ltd., Johannesburg, South Africa.

Jones, R.A., and P.B. Kaufman. 1971. Regulation of growth in Avena stem segments by gibberellic acid and kinetin. Physiol. Plant. 24:491-497.

Kaufman, P.B. 1965a. The effects of growth substances on intercalary growth and cellular differentiation in developing internodes of Avena sativa. I. The effects of indole-3-acetic acid. Physiol. Plant. 18:424-443.

Kaufman, P.B. 1965b. The effects of growth substances on intercalary growth and cellular differentiation in developing internodes of Avena sativa. II. The ef fects of gibberellic acid Physiol. Plant. 18:703-724.

Kaufman, P.B. 1967. Role of gibberellins in the control of intercalary growth and cellular differentiation in developing Avena internodes. Ann. N.Y. Acad. Sci. 144:191-203.

Kaufman, P.B., W.C. Bigelow, L.B. Petering, and F.B. Drogosz. 1969a. Silica in developing epidermal cells of Avena internodes: Electron microprobe analysis. Science 166:1015-1017.

Kaufman, P.B., T.G. Brock. I. Song, Y.B. Rho, and N.S. Ghosheh. 1987. How cereal grass shoots perceive and respond to gravity. Am. J. Bot. 74:1446-1457.

Kaufman, P.B., and S.J. Cassell. 1963. Striking features in the development of internodal epidermis in the oat plant ( $A$ vena sativa). Mich. Bot. 2:115-121.

Kaufman, P.B., S.J. Cassell, and P.A. Adams. 1965. On the nature of intercalary growth and cellular differentiation in internodes of A vena sativa. Bot. Gaz. 126:1-13.

Kaufman, P.B. and P. Dayanandan. 1983. Gibberellin-induced growth in Avena internodes. p. 129-157. In The biochemistry and physiology of gibberellins. Vol. 2. Praeger Publ., New York.

Kaufman, P.B., P. Dayanandan, Y. Takeota, W.C. Bigelow, J.D. Jones, and R. Iler. 1981. Silica in shoots of higher plants. p. 409-449. In T. Simpson and B. Volcani (ed.) Silicon and siliceous structures in biological systems. Springer-Verlag New York, New York.

Kaufman, P.B., P. Dayanandan, and C.I. Franklin. 1985. Structure and function of silica bodies in the epidermal system of grass shoots. Ann. Bot. 55:487-507.

Kaufman, P.B., and R.A. Jones. 1974. Regulation of growth in Avena sativa (oat) stem sections by gibberellic acid and abscisic acid. Physiol. Plant. 51:39-43. 
Kaufman, P.B., L.B. Petering, and P.A. Adams. 1969b. Regulation of growth and cellular differentiation in developing Avena internodes by gibberellic acid and indole-3-acetic acid. Am. J. Bot. 56:918-927.

Kaufman, P.B., L.B. Petering, and J.G. Smith. 1970a. Ultrastructural development of corksilica cell pairs in Avena internodal epidermis. Bot. Gaz. 131:173-185.

Kaufman, P.B., L.B. Petering, and S.L. Soni. 1971. Ultrastructural studies on cellular differentiation in internodal epidermis of Avena sativa. Phytomorphology 20:281-309.

Kaufman, P.B., L.B. Petering, C.S. Yocum, and D. Baic. 1970b. Ultrastructural studies on stomatal development in internodes of Avena sativa. Am. J. Bot. 57:33-49.

Kaufman, P.B., and I. Song. 1987. Hormones and the orientation of growth. p. 375-392. In P.J. Davies (ed.) Plant hormones and their role in plant growth and development. Martinus Nijhoff, Dordrecht, Netherlands.

Kleim, F. 1937. Vegetationspunkt und Blattanlage bei Avena sativa. Beitr. Biol. Pflanz. 24:281-310.

Koning, R., A. Tkaczyk, P.B. Kaufman, R.P. Pharis, and W. Morf. 1977. Regulation of internodal extension in Avena shoots by the inflorescence, nodes, leaves and intercalary meristem. Physiol. Plant. 40:119-124.

O'Brien, T.P., and K.V. Thimann. 1965. Histological studies on the coleoptile. I. Tissue and cell types in the coleoptile tip. Am. J. Bot. 52:910-918.

O'Brien, T.P., and K.V. Thimann. 1967. Observations on the fine structure of the oat coleoptile. III. Correlated light and electron microscopy of the vascular tissues. Protoplasma 63:443-478.

Simpson, T.L., and B.E. Volcani. 1981. Silicon and siliceous structures in biological systems. Springer-Verlag New York, New York.

Song, I., C.R. Lu, T.B. Brock, and P.B. Kaufman. 1988. Do starch statoliths act as the gravisensors in cereal grass pulvini? Plant Physiol. 86:1155-1162.

Stanton, T.R. 1955. Oat identification and classification. USDA Tech. Bull. 1100. U.S. Gov. Print. Office, Washington, DC.

Thimann, K.V. 1977. Hormone action in the whole life of plants. The Univ. of Massachusetts Press, Amherst.

Thimann, K.V., and T.P. O'Brien. 1965. Histological studies on the coleoptile. II. Comparative vascular anatomy of coleoptiles of Avena and Triticum. Am. J. Bot. 52:918-923. 
